\title{
Phylogenetic study of mangrove associate grass Myriostachya wightiana (Nees ex Steud.) Hook. f. using rbcL gene sequence
}

\author{
Kiran Kumar $\mathrm{M}^{*}$ \& Sandeep B V \\ Department of Biotechnology, College of Science and Technology, Andhra University, Visakhapatnam, Andhra Pradesh, India \\ *Email: kiranbiotech65@gmail.com
}

\section{ARTICLE HISTORY}

Received: 14 February 2021

Accepted: 05 May 2021

Available online: 01 July 2021

\section{KEYWORDS}

PCR amplification

BLASTn

MEGAX

Multiple sequence alignment

Poaceae
ABSTRACT

Myriostachya is a monotypic genus in the family Poaceae, with the only known species Myriostachya wightiana (Nees ex Steud.) Hook.f. It is a mangrove associate grass primarily distributed along the muddy streams and channels in intertidal mangrove swamps of India, Bangladesh, Sri Lanka, Myanmar, Thailand and Sumatra. Molecular identification and evolutionary studies of M. wightiana is unreported till now. Therefore, in this study, the phylogenetic analysis of $M$. wightiana was established with related family members by using chloroplast rbcL gene-based systematics. The molecular phylogeny was accomplished by DNA extraction, PCR amplification and sequencing of the rbcL gene and phylogenetic analysis. The genomic DNA was extract using the CTAB method and the rbcL gene amplification is by using the F-5'ATGTCACCACAAACAGAAACTAAAGC3 and R5'CTTCGGCACAAAATAAGAAACGATCTC3' primers. Phylogenetic analysis of M. wightiana was performed by multiple sequence alignment with UPGMA, and the Maximum-parsimony phylogenetic tree was constructed using MEGAX. Myriostachya wightiana rbcL gene sequence shows the highest similarity to Paspalum species, and in the phylogenetic tree $M$. wightiana has a close branch with Paspalum vaginatum. The evolutionary divergence from $M$. wightiana is maximum (0.49) to Sorghum propinquum and minimum (0.01) to Oryza officinalis and Oryza punctata. This study concluded that $M$. wightiana has a strong morphological and phylogenetic relationship with salt-tolerant Paspalum sp.

\section{Introduction}

Myriostachya is monotypic genus in the Poaceae family, with Myriostachya wightiana (Nees ex Steud.) Hook. f. being the only species (1). The species is tropical with, its native range from the Indian Subcontinent to West Malesia. It is widely located in the intertidal mangrove swamps of India, Bangladesh, Sri Lanka, Myanmar, Thailand and Sumatra (2). In India, it is mainly distributed on the southeast coast of the Bay of Bengal. M. wightiana is a large, densely clumped perennial grass growing up to 3 meters. It frequently occurs along with Acanthus ilicifolius L., Nypa fruticans Wurmb. and Porteresia coarctata (Roxb.) Tateoka. The species grows well in saline water habitat rather than fresh water due to structural adaptations like the thick epidermis, sclerenchymatous vascular system, salt secretion glands, conspicuous metaxylem and broad phloem region in stem and leaf, dense cortex and lignified root exodermis (3).

The taxonomic position of $M$. wightiana is recorded based on the morphological features. However, the morphology-based systematics and evolutionary studies of Poaceae are not reliable due to the higher number of taxa, simplicity of floral architecture and vegetative structure, dynamic and mosaic evolution (4). Because of these challenges, DNA based molecular systematics are being used to generate promising results. According to the available literature, the evolutionary studies of $M$. wightiana have not been carried out yet. Thus, this study aims to build phylogenetic relationships of $M$. wightiana by DNA dependent molecular systematics. DNA barcoding is a relatively quick and accurate method for identification of any plant or animal species (5). DNA barcoding can be used in molecular systematics to identify the new species in conjugation with conventional taxonomic approaches (6). The fundamental principle of DNA sequence utilisation in phylogenetic analysis is the occurrence of nucleotide changes over time. Therefore, the estimation and reconstruction of evolutionary relationships between different organisms are possible (7).

In plants, the chloroplast genome is quite helpful for evolutionary and phylogenetic experiments, especially above the species level because of its relatively abundant DNA material, single-copy genes,

(c) Kiran \& Sandeep (2021). This is an open-access article distributed under the terms of the Creative Commons Attribution License, which permits unrestricted use, distribution and reproduction in any medium, provided the original author and source are credited (https://creativecommons.org/licenses/by/4.0/). 
conservative nucleotide substitution rate. Therefore, most phylogenetic reconstruction carried out so far in plant systematics is based on molecular evidence from the cp DNA genes. The plastid-encoded rbcL gene is the most widely used gene to establish molecular phylogeny (8). The rbcL gene is a singlecopy gene with approximately 1430 base pairs length, and it is free from longitudinal mutations, thereby showing a fair conservative rate of evolution (9). Chloroplast rbcL gene is responsible for encoding the largest subunit of ribulose 1,5 carboxylase/oxygenase bisphosphate (RUBISCO/RUBPCase) which consists of all the active sites of the enzyme. Environmental factors could be the selective pressure to increase the $\mathrm{CO}_{2}$ utilisation efficiency of RUBISCO through adaptive evolution of the rbcL gene (10). This study aims to establish $M$. wightiana phylogenetic relationship with related family members using the chloroplast rbcL gene.

\section{Materials and Methods}

\section{Sample collection}

Healthy and young $M$. wightiana (Fig. 1) plant material were collected from the mangroves (Fig. 2) of Bhavanapadu (Long: $18^{\circ} 33^{\prime} 52^{\prime \prime}$ to $18^{\circ} 32^{\prime} 11^{\prime \prime} \mathrm{N}$; Lat: $84^{\circ} 21^{\prime} 26^{\prime \prime} \mathrm{E}$ to $84^{\circ} 18^{\prime} 22^{\prime \prime} \mathrm{E}$ ) which is located in the northeast of Andhra Pradesh, adjoining the Bay of Bengal, India. The collected plant samples were aseptically transferred to the zip bags and transported to the laboratory. The plant species was authenticated by Dr. S. Hara Sreeramulu, Taxonomist, Department of Botany, Dr. V. S. Krishna College. Visakhapatnam and the voucher specimen (No. 00564/AP) was deposited at the Herbarium, Department of Botany, Andhra University.

\section{DNA extraction}

Total DNA content was extracted from the leaves of $M$. wightiana was carried out by the CTAB method (11). Surface sterilised healthy and young leaves were grounded using liquid nitrogen and $500 \mu \mathrm{g}$ of

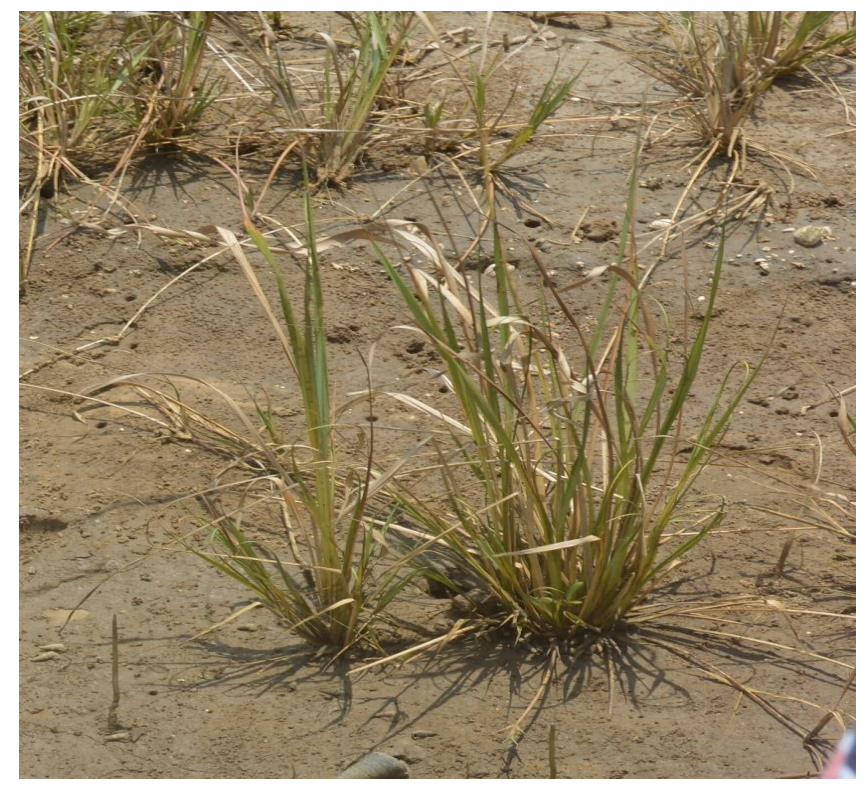

Fig. 1. Myriostachya wightiana (Nees ex Steud.) Hook. f. grounded leaf powder was mixed with $750 \mu$ l of CTAB, $20 \mu \mathrm{l}$ of mercaptoethanol in a $2 \mathrm{ml}$ Eppendorf tube. The mixture was vortexed intermittently and then incubated in a water bath at $65^{\circ} \mathrm{C}$ for $45 \mathrm{~min}$. After incubation, the mixture was allowed to cool until it reaches room temperature. Subsequently, 750 $\mu \mathrm{l}$ of chloroform/isoamyl alcohol (24:1) was added to the mixture, and the tube was centrifuged at 12000 rpm (Eppendorf, 5810R) for $10 \mathrm{~min}$ and the upper aqueous phase was separated into a new tube. The chloroform/isoamyl alcohol extraction was repeated twice to the aqueous phase and centrifuged for $5 \mathrm{~min}$. To the resultant supernatant, $0.1 \mathrm{ml}$ of $3 \mathrm{M}$ sodium acetate ( $\mathrm{pH} 4.6$ ), 2 vol. of 95\% ethanol was added and incubated at $-20^{\circ} \mathrm{C}$ for $1 \mathrm{hr}$ to precipitate DNA. Then the precipitate was centrifuged at $12000 \mathrm{rpm}$ for 10 min. The DNA pellet was washed twice with $750 \mu \mathrm{l}$ of $70 \%$ ethanol, then centrifuged for 10 minutes at $10000 \mathrm{rpm}$. The resulting DNA pellet was rewashed twice with $96 \%$ ethanol and dried in a desiccator for $15 \mathrm{~min}$. The DNA pellet was stored in a $-20{ }^{\circ} \mathrm{C}$ freezer. The quantity of isolated DNA was estimated by diphenylamine test (12) and the quality was estimated using 1\% agarose gel electrophoresis (BioRad, Mini-sub cell GT electrophoresis system). The gels were visualised in a UV transilluminator (Invitrogen, LB0100) and the image was captured by using a Gel documentation system.

\section{PCR amplification and sequencing of rbcL gene}

Myriostachya wightiana chloroplast $\mathrm{rbcL}$ gene amplification was conducted using primers, rbcL F5'ATGTCACCACAAACAGAAACTAAAGC3' (13) and rbcL R-5' CTTCGGCACAAAATAAGAAACGATCTC 3' (14). A $20 \mu \mathrm{l}$ of PCR reaction mixture comprising 1 unit of pfu DNA polymerase, $2 \mu$ of 10X PCR buffer with 20 $\mathrm{mM} \mathrm{MgSO}_{4}, 2 \mu \mathrm{l}$ of $2 \mathrm{mM}$ dNTPs, $2 \mu \mathrm{l}$ of $10 \mathrm{M}$ each primer, and $25 \mathrm{ng}$ of template DNA. The PCR amplification (Bio-Rad, PTC-200) was conducted for 35 cycles. The thermocycler temperature configuration was started with the initial denaturation for 5 minutes at $94{ }^{\circ} \mathrm{C}$, then continued to 35 cycles with denaturation for 30 seconds at $94^{\circ} \mathrm{C}$, annealing for 40 seconds at $50{ }^{\circ} \mathrm{C}$, extension for 1 minute at $72{ }^{\circ} \mathrm{C}$, and the final cycle extension time at $72{ }^{\circ} \mathrm{C}$ was raised to 7 minutes. The amplified rbcL PCR products were observed using $1.4 \%$ agarose gel electrophoresis with ethidium bromide staining, a column-based DNA purification kit purified the single band PCR amplicons. The purified PCR product was subjected to the Sanger's di-deoxy sequencing in both forward and reversed directions using an ABI prism 3700 DNA analyser. The resultant chloroplast rbcL sequence of $M$. wightiana was submitted to the NCBI database (accession number KY293284).

\section{Sequence alignment and Phylogenetic analysis}

The evolutionary analysis of $M$. wightiana was conducted by constructing a phylogenetic tree with some major species of Poaceae. Myriostachya wightiana rbcL gene sequence was subjected to the BLASTn in the NCBI server to identify the homologous sequence or species. From the NCBI database, 33 species were selected based on their degree of homology with the target $\mathrm{rbcL}$ gene sequence. The selected 33 


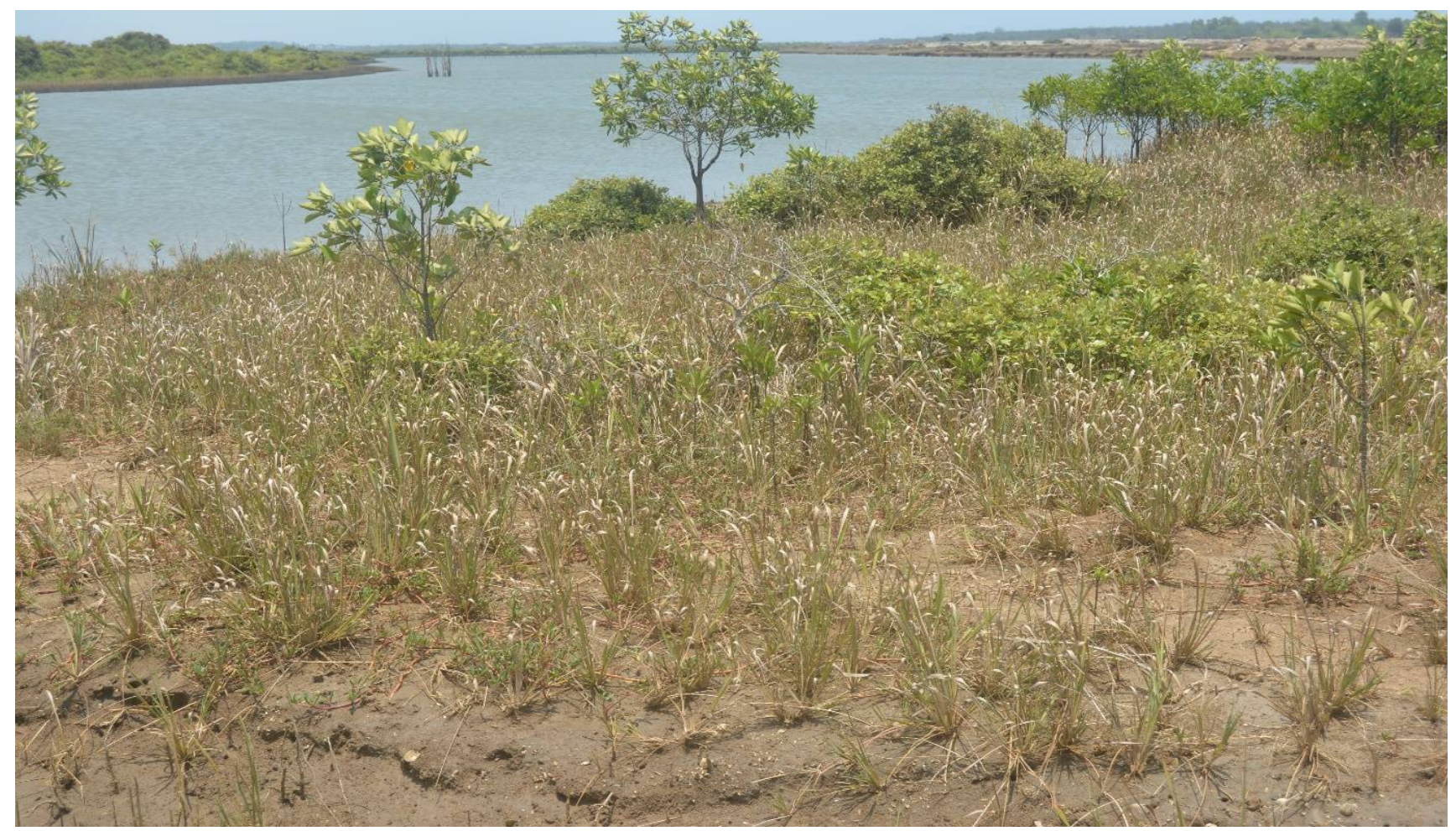

Fig. 2. Habitat of Myriostachya wightiana (Nees ex Steud.) Hook. f.

species' rbcL gene sequences were derived from the nucleotide NCBI database. In the selected thirty-three species for phylogenetic analysis, thirty species belong to the Poaceae family, and the remaining three species were used as an outgroup that consists of marine algae Saccharina latissimi (L.) C.E.Lane, C.Mayes, Druehl and G.W.Saunders., Undaria pinnatifida (Harv.) Suringar and Porphyra haitanensis T.J.Chang and B.F.Zheng, 1960. which belongs to Laminariaceae, Alariaceae and Bangiaceae respectively. The marine algae were used as an out group to known the evolutionary progress from the marine algae to marine grasses and to terrestrial grasses. Multiple sequence alignment was conducted with an advanced cluster method UPGMA using Muscle embedded in MEGAX to search homology of $\mathrm{rbcL}$ gene sequences between the $M$. wightiana and the selected 33 species. To analyse the variations among the sequences, a distance matrix was determined, and based on the differences expressed in the distance matrix; a maximum-parsimony tree was constructed using MEGAX. The evaluation of phylogenetic tree topologies was done by the bootstrap method with 1000 replicates for all nodes (15).

\section{Results and Discussion}

\section{DNA extraction and quantification}

The result was given as Mean \pm Standard Deviation obtained from three independent experiments. As part of DNA barcoding, the complete genome of $M$. wightiana was successfully extracted. The isolated DNA appeared as a prominent band on 1\% agarose gel (Fig. 3A) and the isolated total DNA content was measured as $663 \pm 54 \mu \mathrm{g} / \mathrm{gm}$. DNA barcoding is one of best way to classify new species and also to collect a database of the reference sequences (16).

\section{PCR amplification and sequence analysis}

The PCR amplified $M$. wightiana chloroplast rbcL gene was successfully run by the $1.5 \%$ agarose gel electrophoresis. In the agarose gel (Fig. 3B), the first well shows marker DNA and the remaining three wells indicate amplified rbcL gene product. The thick and single bands in the agarose gels indicate that the rbcL gene amplification was done successfully, and the size of the amplified $M$. wightiana rbcL gene was approximately $\pm 650 \mathrm{bp}$. The yield and consistency of DNA bands in the agarose gels determines the universality of selected primers and their discriminating strength. According to one report, universal primers identify the regions in the rbcL gene of Angiosperms and display a high degree of universality in terrestrial plants (14). The direct nucleotide sequencing of PCR amplified products is now emerging as an important field of evolutionary studies and systematics (17). An ideal DNA barcode can be recovered and gives maximum discrimination among species with a single pair of primers suitable for bidirectional sequencing with a minor sequence modification. The chloroplast rbcL gene contains the least number of variable regions and it is referred to as a best-characterised gene that is easily retrievable with common PCR primers. It was proposed that, out of the nuclear and plastid genomes, plastid genomes are used for phylogenetic research in plants since they are thought to have similar ancestors (18). Our research used the chloroplast rbcL gene sequence, considering that the rbcL gene is quickly amplified and sequenced in many terrestrial plants and impacts in phylogenetic studies by placing the species in a correct genus and plant family. 


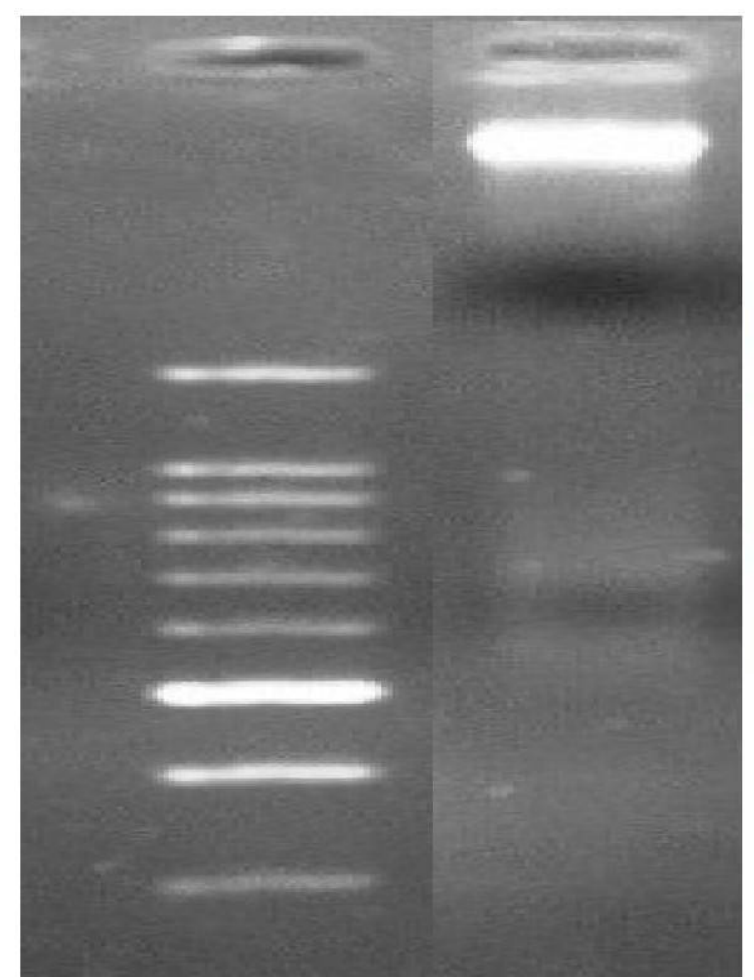

A

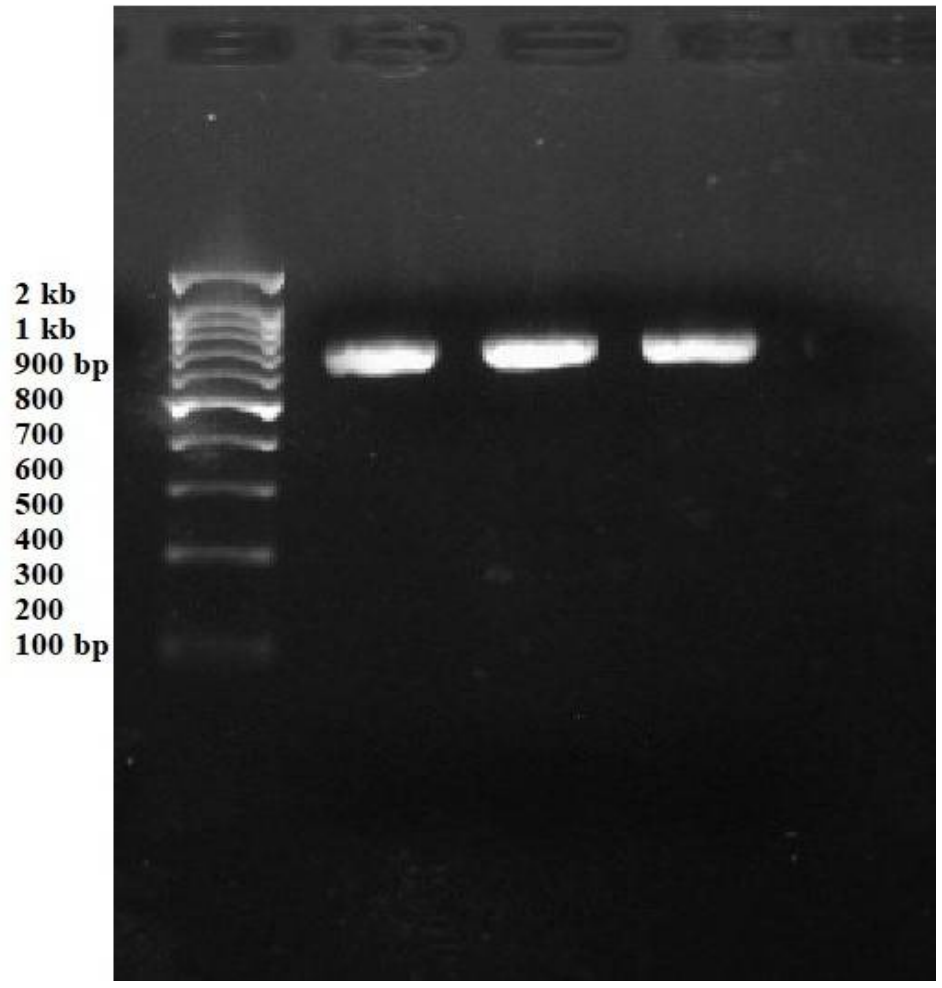

B

Fig. 3. (A) Photograph showing genomic DNA band in 1\% agarose gel. (B) Photograph showing the PCR amplified rbcL gene band in $1.5 \%$ agarose gel.

M. wightiana chloroplast $\mathrm{rbcL}$ gene nucleotide composition was computed by Seqstate V.1.21 server (19). The amplified conserved region of the rbcL gene (GenBank Accession No. KY293284) has 604 nucleotides and was estimated to have a molecular weight of $373 \mathrm{KDa}$. The nucleotide composition of the rbcL gene consists of $164 \mathrm{bp}$ Adenine (A), $173 \mathrm{bp}$ Thymine (T), 140 bp Guanine (G), 127 bp Cytosine (C), and the percentage of GC was measured as 44.2. The Extinction coefficient of the $M$. wightiana $\mathrm{rbcL}$ gene is estimated to be $9805831 \mathrm{Mol}^{-1} \mathrm{~cm}^{-1}$. Kusumi and Tachida (20) reported that the GC content in the plants differs from $28-42 \%$. It has been reported that the GC content of the rbcL gene in wild Solanum sp. is $43.9 \%$ (21). The current findings showed that the rbcL genes in $M$. wightiana have comparatively low GC content.

\section{Multiple sequence alignment and phylogenetic tree analysis}

The BLAST search results showed similar rbcL gene sequences of other species with their percentage of identity against the $M$. wightiana $\mathrm{rbcL}$ gene sequence. The BLASTn results revealed that the $M$. wightiana rbcL gene sequence showed the highest similarity to Paspalum sp., with an identity of $99 \%$ and an E-value of 0.0 . From the hits, a total of $33 \mathrm{rbcL}$ gene sequences from different species were selected to construct evolutionary relationships through multiple sequence alignment using the UPGMA program in MEGAX. The multiple sequence alignments indicated a variable number of deletions and insertions in the chloroplast rbcL. The phylogenetic parameters such as variance, parsimony sites, and overall mean distance were calculated as $0.52,0.32$ and 0.1 respectively in the
rbcL alignments of family Poaceae. The evolutionary divergence of $M$. wightiana with its other species of Poaceae was determined. A satisfactory result was established by using the rbcL gene as a marker to evaluate the phylogenetic relationship among the grass species. The evolutionary divergence among sequences at the generic level varies from 0.01-0.49. $M$. wightiana showed the highest evolutionary divergence with the species of Sorghum propinquum (Kunth) Hitchc. (0.49), Undaria pinnatifida (Harv.) Suringar (0.33) and Porphyra haitanensis T.J.Chang and B.F.Zheng. Whereas $M$. wightiana shows the least evolutionary divergence with the species of Oryza officinalis Wall., (0.01), O. punctata Kotschy ex Steud. (0.01), O. glaberrima Steud. (0.02) and $O$. nivara S.D.Sharma and Shastry (0.02). Multiple sequence alignments of the rbcL gene sequences revealed that the rbcL gene is highly conserved throughout the Poaceae family.

In the phylogenetic tree (Fig. 4), there were five main clades. The first main clade consists of two subclades. The first subclade of main clade-I composed Paspalum sp. and the second subclade composed of Zea and Sorghum species. The second and third main clades consist of Triticum and Oryza species. The fourth main clade composed only Sorghum propinquum. The fifth main clade consists of marine macroalgae Porphyra haitanensis, Saccharina latissimi and Undaria pinnata. The phylogenetic tree indicated that the $M$. wightiana found a close branch with Paspalum vaginatum Sw. (GenBank Accession No. LN907995). In the phylogenetic tree, the clades are organised mainly with several species in the same genus according to their similarities. $M$. wightiana is known to be the nearest species to seashore grasses in phylogenetic analysis. 


\section{Conclusion}

An ideal taxonomic recognition of species is essential for the proper management of any organism. Specieslevel evolutionary information of a plant can be provided by the chloroplast rbcL gene based phylogenetic analysis. The present study of rbcL gene sequence and phylogenetic analysis explored the evolutionary divergence and relatedness of the $M$. wightiana. The rbcL gene sequence and multiple sequence alignment revealed that the $M$. wightiana showed 99\% homology to Paspalum sp. The evolutionary divergence from $S$. propinquum to $M$. wightiana was estimated as 0.49 , which was found maximum and the minimum was for $O$. officinalis and $O$. punctata that are 0.01 . From the molecular phylogeny by the rbcL gene, it was concluded that the

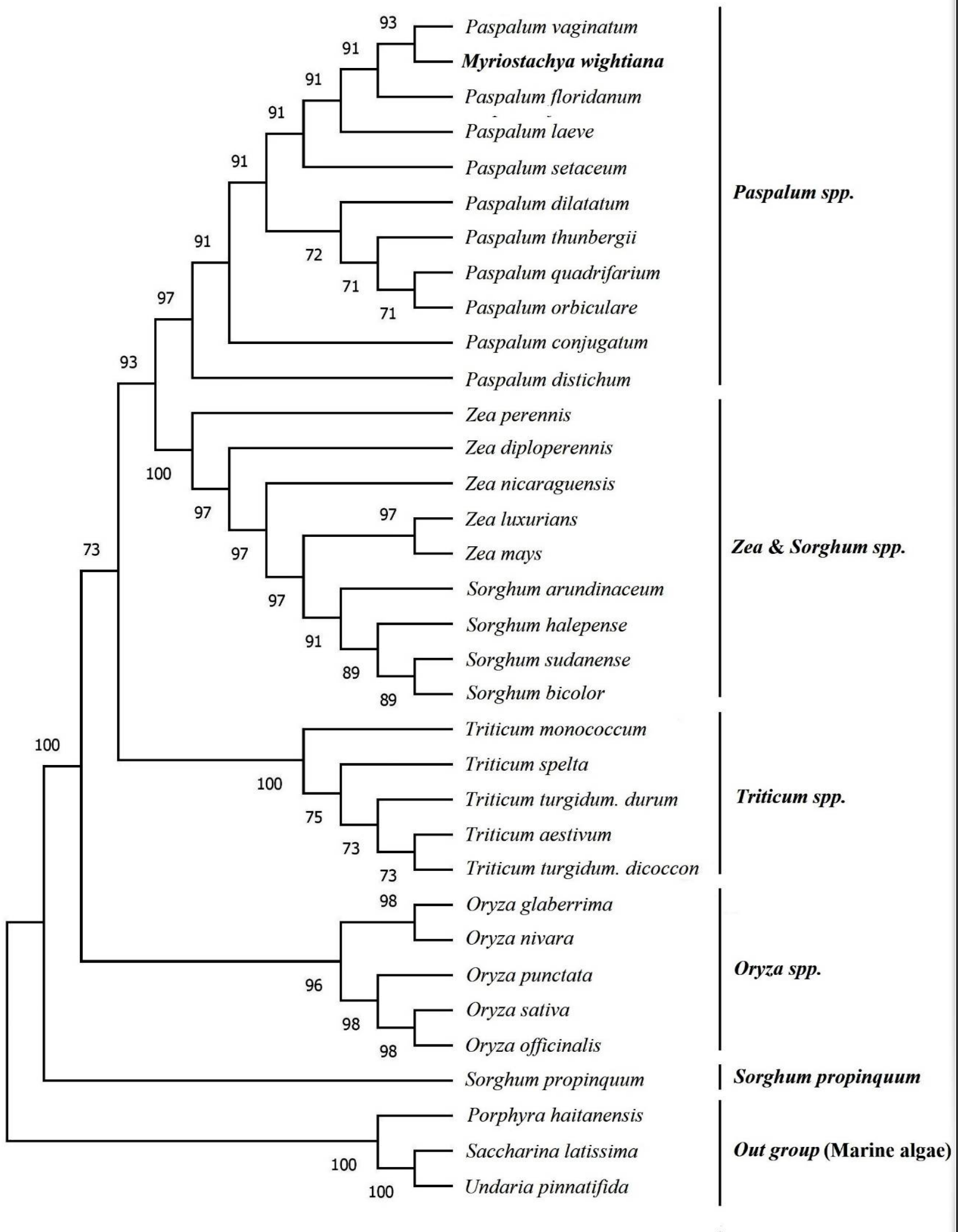

Fig. 4. Maximum Parsimony tree of Myriostachya wightiana and other species based on the rbcL gene. Bootstrap values are indicated on the branches. 
$M$. wightiana has a strong relationship to salt-tolerant grasses like Paspalum sp.

\section{Acknowledgements}

The authors are thankful to the Department of Biotechnology, Andhra University, Visakhapatnam, for providing the laboratory facilities to execute the current research work. This research work has been conducted with financial support from University Grants Commission (UGC), Govt. of India.

\section{Authors' contributions}

MKK carried out isolation of rbcL gene, sequencing, multiple sequence alignment, construction of the phylogenetic tree and drafting of the manuscript. BVS participated in the design and planning of research work, helped to write the article and corrected the manuscript. The final manuscript was read and approved by all the authors.

\section{Conflict of interests}

The authors declare that there are no conflicts of interest.

\section{Supplementary file}

Table 1. Estimates of evolutionary divergence among the selected species.

\section{References}

1. Hooker JD,. The Flora of British India. 1897;7:327-28.

2. Gilliland HB. A revised flora of Malaya, The Royal Botanic Gardens, Singapore. 1971;3:1-319.

3. Rashid P, Ahmed A. Anatomical adaptation of Myriostachya wightiana Hook. f. to salt stress. Dhaka Univ. J Biol Sci. 2011; 20(2):205-08. http://doi.org/10.3329/dujbs.v20i2.8982

4. Stebbins GL. Grass systematics and evolution: past, present and future. In: Soderstrom TR, Hilu KW, Campbell CS, Barkworth ME (editors.). Grass Systematics and Evolution. Washington D.C: Smithsonian Institute; 1987. P. 359-67.

5. Walker JM. Methods in Molecular Biology. TM Series editor. Life Sciences. UK: University of Hertfordshire; 2009. Vol. 531.

6. Prendini L. Scorpion diversity and distribution in southern Africa: pattern and process. In: Huber BA, Sinclair BJ, Lampe $\mathrm{KH}$ (editors.). In: African Biodiversity: Molecules, Organisms, Ecosystems, Proceedings of the $5^{\text {th }}$ International Symposium on Tropical Biology. Bonn, Germany. New York; 2005. p. 25-68.

7. Dharmayanti NLPI. Filogenetika molekuler: metode taksonomi organisme berdasarkan sejarah evolusi. Wartazoa. 2011;21:1-10.

8. Donoghue MJ, Olmstead RG, Smith JF, Palmer JD. Phylogenetic relationships of Dipsacales based on rbcL sequences. Annals of the

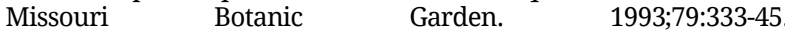
http://doi.org/10.2307/2399772
9. Doebley J, Durbin M, Golenberg EM, Clegg MT, Ma DP Evolutionary analysis of the large subunit of carboxylase (rbcL) nucleotide sequence among the grasses (Gramineae). Evolution 1990;44:1097-08. http://doi.org/10.1111/j.1558-5646.1990.tb03828.x

10. Lin MT, Occhialini A, Andralojc PJ, Parry MAJ, Hanson MR. A faster Rubisco with potential to increase photosynthesis in crops. Nature. 2014; 513: 547-50. http://doi.org/10.1038/nature13776

11. Yoon CS, Glawe DA, Shaw PD. A method for rapid small-scale preparation of fungal DNA. Mycologia. 1991;83:835-38.

12. Gendimenico GJ, Bouquin PL, Tramposch KM. Diphenylaminecolorimetric method for DNA assay: a shortened procedure by incubating samples at $50^{\circ} \mathrm{C}$. Anal Biochem. 1988; 173:45-48. http:// doi.org/10.1016/0003-2697(88)90156-X

13. Levin RA, Wagner WL, Hoch PC, Nepokroeff M, Pires JC, Zimmer EA, Sytsma KJ. Family-level relationships of Onagraceae based on chloroplast rbcL and ndhF data. American Journal of Botany. 2003;90:107-15. http://doi.org/10.3732/ajb.90.1.107

14. Kress WJ, Erickson DL. A two-locus global DNA barcode for land plants: The coding rbcL gene complements the noncoding trnHpsbA spacer region. PLoS ONE 2. 2007; e508. http://doi.org/10.1371/ journal.pone.0000508

15. Felsenstein J. Confidence limits on phylogenies: an approach using the bootstrap. Evolution 1985b;39:783-91. http://doi.org/10.1111/j1558-5646.1985.tb00420.x

16. Gutteridge A, Burns M. The Application of DNA Molecular Approaches for the Identification of Herbal Medicinal Products. Journal of the Association of Public Analysts. 2013;41:53-66.

17. Clegg MT, Zurawski G. Chloroplast DNA and the study of plant phylogeny. In: Soltis PS, Soltis DE, Doyle JJ, editors. Molecular systematics of plants. Chapman and Hall: New York; 1991. p.1-13.

18. Raven JA, Allen JF. Genomics and chloroplast evolution: what did cyanobacteria do for plants?. Genome Biol. 2003;4(3):209.1-5 http://doi.org/10.1186/gb-2003-4-3-209

19. Muller K. SeqState: primer design and sequence statistics for phylogenetic DNA datasets. Appl Bioinforma. 2005;4:65-69. http://doi.org/10.2165/00822942-200504010-00008

20. Kusumi J, Tachida H. Compositional properties of green plant plastid genomes. J Mol Evol. 2005;60:417-25. http://doi.org/10.1007/ s00239-004-0086-8

21. Rahman IA. Biochemical, molecular and phylogenetic studies of selected wild Solanum sp. of Meghalaya. PhD thesis. Dept. of Botany, North-Eastern Hill University, Shillong; India. 2014. http:// hdl.handle.net/10603/68010

Additional information

Peer review information: Plant Science Today thanks Sectional Editor and the other anonymous reviewers for their contribution to the peer review of this work.

Reprints and permissions information is available at

https://horizonepublishing.com/journals/index.php/PST/open_access_policy

Publisher's Note: Horizon e-Publishing Group remains neutral with regard to jurisdictional claims in published maps and institutional affiliations.

To cite this article: Kiran K M, Sandeep B V. Phylogenetic study of mangrove associate grass Myriostachya wightiana (Nees ex Steud.) Hook. f. using rbcL gene sequence. Plant Science Today. 2021;8(3):590-595.

https://doi.org/10.14719/pst.2021.8.3.1133

Plant Science Today, published by Horizon e-Publishing Group, is covered by Scopus, Web of Science, BIOSIS Previews, Clarivate Analytics, etc. See https://horizonepublishing.com/journals/index.php/PST/indexing_abstracting 